\title{
THE POLICY OF MINIMUM WAGES IN RUSSIA AND ABROAD
}

\author{
Assoc. Prof. Dr. Anna Andreevna MALAKHOVA ${ }^{1}$ \\ Assoc. Prof. Dr. Irina Igorevna ZYRYANOVA ${ }^{2}$ \\ Assoc. Prof. Dr. Olga Valeryevna STAROVA ${ }^{3}$ \\ Assoc. Prof. Dr. Dmitry Valeryevitch ZYABLIKOV ${ }^{4}$ \\ ${ }^{1}$ Siberian Federal University, Russia \\ ${ }^{2}$ Siberian Federal University, Russia \\ ${ }^{3}$ Siberian Federal University, Russia \\ ${ }^{4}$ Siberian Federal University, Russia
}

\begin{abstract}
In this paper the negative social and economic consequences of raising the minimum wage for the regional economy on the example of Krasnoyarsk Region are discussed. It is shown that in Krasnoyarsk Region regional coefficients and northern wage surcharges have been established, and according to the Constitutional Court Decree No. 38-P of 07.12.2017 employers are obliged to charge them in excess of the minimum wage. As a result, the social guaranteed minimum wages in the region is even higher factually than the subsistence level. This situation leads to a fairly rapid growth of the minimum wage, which is a socially significant phenomenon. It should be noted that despite this expansionary wage growth, this social security measure remains incommensurable compared to similar values abroad. At the same time, the burden on the business sector is excessive, which implies negative consequences for the entire economy and, above all, the growth of the informal sector in the labor market and shadow economy growth as well. Various foreign and domestic theories of the minimum wages regulation are discussed in this paper. This policy should include certain leverage to support small business. It is also necessary to study the impact of the minimum wages growth on the economy of the region and to evaluate its socio-economic consequences. It is suggested that regions should be given the right to establish the minimum wage.
\end{abstract}

Keywords: minimum wages, wages and salaries, subsistence minimum, entrepreneurship, regional coefficients, northern wage surcharges.

\section{INTRODUCTION}

The minimum social guarantee for labor remuneration has always been a necessary and indispensable element of the social and labor relations and social policy of any state as a whole. It is the main indicator characterizing the standard of living in the country [1, pp. 881-888]. There are many theories and various discussions about the calculation of both the size of the minimum wage and the mechanism for its establishment.

Trade unions of all countries are struggling for raising the minimum wage, but there are theories proving that the growth of minimum wage can have a negative impact on the economy and social sphere of citizens. 
The negative consequences of raising the minimum wage are highlighted a lot in foreign scientific literature. Suffice it to recall critics of the neoclassical direction of the economy, such as Pierangelo Garegnani, Robert L. Vienneau, Arrigo Opocher, Ian Steedman, Piero Sraffa, Gary Fields. Their works are based on the concept of market self-regulation via the mechanisms of supply and demand in all markets, including the labor market. This means that if the size of the minimum wage is set above the equilibrium level then there is an excess of labor, or unemployment.

Russian economists also speak about the negative impact of the SMIC growth. For example, V.E. Gimpelson and R.I. Kapelyushnikov explain how the growth of the minimum wage leads to the growth of the informal sector in the economy [2, pp. 6588].

Nevertheless, in many European countries SMIC is quite high and it does not have a negative impact on the economy and social sphere. In 2018, the minimum wage in the UK was 1401 euro, in Germany and France - 1498 euro, in Belgium - 1563 euro, in the Netherlands - 1578 euro, in Ireland - 1614 euro. The absolute leader is Luxembourg with 1999 euro per month [3]. It is worth noting that the minimum wage in the US was 1048 euro per month in January 2018 [4].

The aim of this paper is to analyze the economic results and the possibilities of raising the minimum social guarantee for labor remuneration in Russia up to comparable indicators of the developed countries.

From January 1, 2018 in Russia the minimum wage was raised to 9,489 rubles per month (Article 3 of Federal Law No. 421-FZ of December 28, 2017 "On Amending Certain Legislative Acts of the Russian Federation Regarding Increasing the Minimum the size of wages to the subsistence minimum of the working population"), in terms of the euro rate this amounts to about 128 euros in the beginning of 2018 [5].

The minimum wage in Russia has grown steadily recent years. It is known that the Labor Code of the Russian Federation initially provided that the minimum wage should be equal to the subsistence level of the working population. However, the state could not ensure the implementation of this rule in time and introduced an order for a phased increase of the minimum wage.

The minimum wage established in January 1, 2018, corresponds to $85 \%$ of the subsistence minimum. From May 1, 2018, the minimum wage amounts to 11,163 rubles per month (150 euro), which is equivalent to $100 \%$ of the subsistence minimum of the working population for the second quarter of 2017 (Federal Law No. 421-FZ of December 28, 2017 "On Amending certain legislative acts of the Russian Federation with regard to raising the minimum wage to the subsistence level of the working population"). Starting from 2019, the amount of the minimum wage will be determined annually on the basis of the subsistence minimum of the working population in the whole of the Russian Federation for the second quarter of the previous year.

The increase in the minimum wage is certainly a socially significant phenomenon, but in the context of Russia's crisis economy, an increase in the minimum wage may cause not only positive but also negative effects. 
Let us generalize the negative effects of raising the minimum wage in the economy. These include:

- an obstacle to reducing the costs of firms during an economic downturn, which can lead to inefficiency in the economy, unemployment, poverty, price growth and numerous bankruptcies;

- damage caused primarily to small business;

- decrease in labor demand by reducing the jobs or the working day;

- reducing the cost of wages by shifting the employees to part-time job and paying a certain part of the salary "in the envelope";

- labor productivity growth due to personnel optimization in organizations;

- cost inflation, because the business seeks to compensate its losses setting them into the price;

- increase in budget expenditures to fulfill the liabilities related to the growth of minimum wage;

- transfer of the part of the business to the illegal sector or shutting down the business completely;

- finally, the growth of the minimum wage may lead to the growth of the informal sector in the labor market, that is, employment without effecting an employment contract.

Almost simultaneously with the growth of the minimum wage, a new normative legislative act was issued, in which the Constitutional Court of the Russian Federation stated that the allowances for work in special climatic conditions are charged in excess of the minimum wage (Decree of the Constitutional Court of the Russian Federation of December 7, 2017 No. 38-P "The constitutionality of the provisions of Article 129, parts one and three of Article 133, parts one, two, three, four and eleven of Article 133.1 of the Labor Code of the Russian Federation in connection with complaints of citizens V.S. Grigorieva, O.L. Deidei, N.A. Kapurina and I.Ya. Kurash”) [6]. Let us precise that in Russia the so-called regional coefficients and the percentage of the northern surcharges are accrued on the amount of wages. Regional coefficients and percentage surcharges are established in accordance with Articles 316, 317 of the Labor Code of the Russian Federation and Articles 10 and 11 of the RF Law of February 19, 1993 No. 4520-1 (as of October 16, 2017) "On the State Guarantees and compensation for people working and living in the Far North and equivalent territories "[7]. This is due to the large length of the country and different geographical climatic conditions. Therefore, to compensate for energy costs in the course of working under unfavorable climatic conditions in Russia, special surcharges are provided: the regional coefficient and the percentage of the northern surcharge. The specified surcharges are calculated on the sum of the final payment to the employee in the form of a coefficient. Their size varies depending on the district and region, since Russia is extensive, and in different parts of it the regional and northern coefficients may differ significantly. In general, the regional 
coefficient varies from 1.1 to 2.0 , and the northern coefficient also varies from 1.1 to 2.0. They are calculated separately. Their functions refer to smoothing various working conditions within the country. To the best of our knowledge there is no such an experience in European countries, and there is no need for such kind of surcharges. European countries are small in length and almost all are under favorable climatic conditions.

So, until recently in Russia, all surcharges, including the regional and the northern ones, were included in the amount of the minimum wage. Such a calculation of wages is stated in art. 129 of the Labor Code of the Russian Federation. However, the Constitutional Court of the Russian Federation introduces changes and justifies it by the fact that the regional coefficient and the percentage of the northern surcharge should be calculated above the top of the minimum wage, that is, in addition, thereby increasing the minimum social guarantee for labor remuneration. As a justification for its position, the Constitutional Court explained that the minimum wage is a general guarantee. It is provided irrespective of the location in which the work is performed, whereas labor under special climatic conditions must be paid in an increased amount. Therefore, the increased payment in connection with work under special climatic conditions should be done after the fulfillment of the requirement for the minimum wage. Otherwise, wages in areas with special climatic conditions will not differ from wages in regions with a favorable climate, which is a violation of the principles of equality and justice.

Due to the regional coefficients and the percentage of the northern surcharge, the minimum social security guarantee (SMIC) in some regions of Russia can vary from 15,182 rubles (205 euro) to 39649 rubles (535 euro).

In Russia, as in the world as a whole, there are spheres of the economy that use lowlabor technologies or are monopolistic, and, consequently, for them an increase in the minimum wage, as well as wages in general, is not so critical.

However, along with this, there are industries in which the bulk of the cost of the final product is labor input. And for these industries an increase in the minimum wage may have a negative impact. All the more so for such spheres as agriculture under the conditions of Siberia, trade and services, where labor constitutes a significant share in the total value of manufactured goods, but at the same time the industries are considered to be low-yielding.

Since the President of the Russian Federation V.V. Putin instructed to ensure the speedy implementation of the Labor Code of the Russian Federation (Article 133), which establishes that the minimum wage should ensure the level of incomes of employees not less than the subsistence level of the working population, then employers in Russia pay particular attention to these decisions in matters of labor remuneration.

Hence, it can be concluded that in different districts and regions of the country there will be different social guarantees for labor remuneration, since the subsistence minimum in the territory of Russia varies at times.

At the same time, the decision of the Constitutional Court of December 7, 2017 No. 38$\mathrm{P}$ does not take into account this fact, as a result of which unequal conditions for 
employers are created in the regions. In the subjects of the Russian Federation, the subsistence minimum is established differentially, taking into account the level of tariffs and prices conditioned by natural and climatic characteristics. In general, in some regions of the Russian Federation (where the regional coefficient and the percentage surcharge are not applied), the wages of workers engaged in unskilled labor are paid at the level of the subsistence minimum, and in regions with special climatic conditions it substantially exceeds it. At the same time, a more significant burden on the wage fund in the production of goods and services negatively affects the competitiveness of enterprises in regions with special climatic conditions. At the same time, the reduction in the size of regional coefficients and the percentage of the northern surcharge is impossible because this is often a significant incentive for attracting labor to areas with severe climatic conditions.

As already noted, the high level of minimum wages in the EU countries is not accompanied by excessive problems for business, which were highlighted above in the Russian economy. The foregoing means only one thing: the minimum social guarantee for wages should depend on the socio-economic parameters of the economy, in particular, on the level of GDP per capita, the share of wages in the structure of GDP and the structure of citizens' incomes, the share of income redistributed through the budget, the size of the optimal tax rates on the Laffer curve and other indicators. For each country there is a 'threshold' level of the minimum wage, after which this social guarantee will turn from good to bad.

\section{CONCLUSION}

Summarizing all of the above, we propose the following measures to stabilize the situation in Russia.

1. Revision of the institution of the establishment of an SMIC in Russia. Transfer of authority to establish SMIC to the management of regions. Subjects of the Russian Federation have different natural, climatic, geological and geographical working conditions. Also, the regions have a different industry structure and other characteristics. Only in the regions regional authorities are able to perform an objective assessment of the minimum social security guarantee for labor in the region. When setting the minimum wage, it is necessary to focus on the possibilities of small business. The minimum social guarantee, if it is universal and equal for all, should be based on the financial resources of such enterprises and in no case jeopardize the very existence of these enterprises, at least in the legal sector. It is now difficult to evaluate the proportion of enterprises that will move into the "shadow" after the rapid growth of the minimum wage.

2. Reduction of insurance premiums for all small business enterprises.

3. Exemption from the tax burden of small business enterprises with compensation for shortfall from the federal budget.

According to the results of this research, "shock absorbers" for the private sector should be developed, which would mitigate the negative effects of the SMIC growth. Only in 
this case an increase in the minimum wage can lead to the maximization of positive effects and to the elimination of negative effects.

\section{REFERENCES}

[1] Sochneva E.N., Malakhova A.A., Malimonov I.V., Kravtsov D.I., Zyablikov D.V. The problem of poverty in Russia: state regulation issues. SGEM International Multidisciplinary Scientific Conference on Social sciences and Arts. 2017. № 1-4. C. 881-888

[2] V.E. Gimpelson, R.I. Kapelyushnikov. To live "in the shadow" or die "in the light": informality on the Russian labor market // Issues of economics. - 2013. - No. 11. - P. 65-88.

[3] Orekhin P. European salaries: Russia did not even dream. Newspaper.ru on 02/27/2018. Access mode: https://www.gazeta.ru/business/2018/02/26/11663749.shtml

[4] Why are the salaries of Russians so small compared to Europe. Access mode: //www.pravda.ru/news/economics/27-02-2018/1372962-money-0//.

[5] Federal Law of the Russian Federation No. 421-FZ of December 28, 2017 "On Amending Certain Legislative Acts of the Russian Federation Regarding Raising the Minimum Wage to the Subsistence Level of the Working Population" URL: https://rg.ru/2017/12/29/fz421-site-dok.html.

[6] Decree of the Constitutional Court of the Russian Federation of December 7, $2017 \mathrm{~N}$ 38-P "On the case on the verification of the constitutionality of the provisions of Article 129, parts 1 and 3 of Article 133, parts 1, 2, 3, 4 and 11 of Article 133.1 of the Labor Code of the Russian Federation in communication with complaints of citizens of V.S. Grigorieva, O.L. Deiday, N.A. Kapurina and I.Ya. Kurash". "Consultant Plus". URL: http://www.consultant.ru/document/cons_doc_LAW_11916/a59730c21f468e7170ae8a1 $78229 \mathrm{db} 5 \mathrm{ee} 6 \mathrm{~d} 862 \mathrm{e} 0 /$.

[7] Federal Law No. 4520-1 of the Russian Federation of February 19, 1993 (as amended on October 16, 2017) "On State Guarantees and Compensations for Persons Who Work and Live in the Far North and Equivalent Territories". URL: http://www.consultant.ru/document/cons_doc_LAW_1786/. 